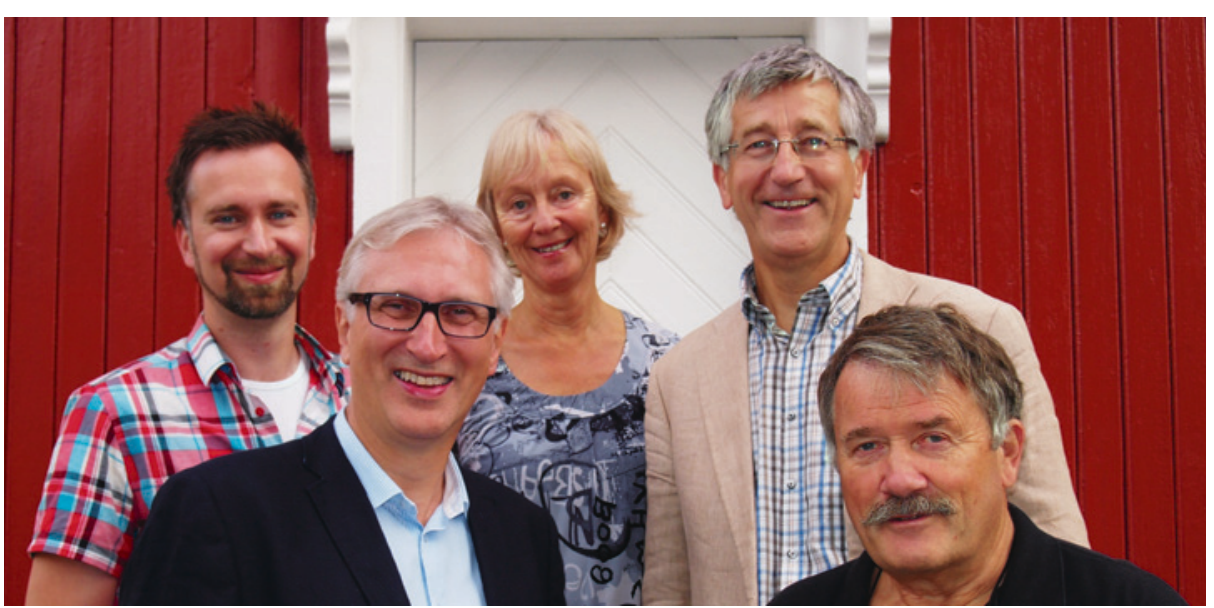

Bak fra venstre Sigurd Høye, Mette Brekke, Morten Lindbæk. Foran fra venstre Svein Gjelstad, Jørund Straand. Foto: Siri Jensen

\title{
Veiledning av leger gir mindre bruk av antibiotika
}

Virale luftveisinfeksjoner skal ikke behandles med antibiotika. Kollegabasert veiledning i riktig bruk av antibiotika gir lavere forskriving.

Forekomsten av infeksjoner med resistente bakterier øker i mange land. Dette skyldes i stor grad overforbruk av antibiotika. Riktigere bruk av antibiotika er det viktigste tiltaket for å begrense utviklingen av resistente bakterier.

Avdeling for allmennmedisin ved Universitetet i Oslo har gjennomført en studie med kollegabasert terapiveiledning i bruk av antibiotika ved luftveisinfeksjoner (1). I Norge er spesialister i allmennmedisin pålagt å delta i etterutdanningsgrupper. Alle de 250 etterutdanningsgruppene i de 11 sørligste fylkene ble invitert til å delta i studien, og 80 av dem aksepterte. Disse ble randomisert til enten intervensjon i form av veiledning fra leger som hadde gjennomgått spesiell opplæring som kollegakonsulent for antibiotikabruk ved luftveisinfeksjoner, eller til kontrollgruppe som fikk veiledning om riktig legemiddelbruk hos eldre (2).

Retningslinjer for riktig antibiotikabruk ble diskutert før hver deltaker la frem en forskrivningsrapport basert på uttrekk fra sine egne elektroniske pasientjournaler. Totalt deltok 450 leger, dvs. omtrent en tidel av alle norske allmennleger.

Etter kurset var relativ risiko 0,80 (95\% KI $0,70-0,89)$ for å få antibiotika hos legene $\mathrm{i}$ intervensjonsgruppene sammenliknet med de andre legene. Relativ risiko for å få bredspektret antibiotika når antibiotika ble forskrevet var $0,80(0,69-0,91)$ hos legene som fikk veiledning sammenliknet med de øvrige legene.

- Denne studien viser betydelig effekt av gruppebasert opplæring rettet mot mange leger, sier lege Svein Gjelstad, som er førsteforfatter av artikkelen. Gjelstad mener at bruken av eksisterende etterutdanningsgrupper som arena for kunnskaps$ø$ kning og bruken av leger som konsulenter har vært avgjørende for effekten.

- Det arbeides nå for at erfaringer fra denne studien kan bli videreført som et landsdekkende tilbud i legers videre- og etterutdanning. Metoden kan brukes på flere kliniske temaer, som for eksempel vanedannende legemidler og henvisningspraksis, sier Gjelstad.

\section{Forskningsgruppen}

Studien er en del av doktorgradsarbeidet til Svein Gjelstad ved Avdeling for allmennmedisin, Universitetet i Oslo, i samarbeid med Antibiotikasenteret for primærmedisin, med Morten Lindbæk og Jørund Straand som veiledere og medforfattere. Øvrige medforfattere var Sigurd Høye, Mette Brekke og statistiker Ingvild Dalen. Prosjektet er finansiert av Legeforeningens kvalitetssikringsfond, Helse- og omsorgsdepartementet og Norges forskningsråds program for klinisk forskning.

\section{Matilde Risopatron Berg}

Tidsskriftet

\section{Litteratur}

1. Gjelstad S, Høye S, Straand J et al. Improving antibiotic prescribing in acute respiratory tract infections: cluster randomised trial from Norwegian general practice (prescription peer academic detailing (Rx-PAD) study). BMJ 2013; 347: f4403.

2. Rognstad S, Brekke M, Fetveit A et al. Prescription peer academic detailing to reduce inappropriate prescribing for older patients: a cluster randomised controlled trial. Br J Gen Pract 2013; 63: e554-62.
Ordforklaringer

Kollegabasert terapiveiledning: Leger som har fått spesiell opplæring innenfor et terapifelt veileder andre leger i riktig praksis innenfor det angitte emnet. Veiledningen foregår i form av kurs i grupper.

Forskrivningsrapport: Oversikt over reseptbelagte medikamenter hver enkelt lege har forskrevet i en gitt periode.

Etterutdanningsgruppe: Spesialister i allmennmedisin i samme geografiske område som møtes et fast antall ganger per år for å holde seg faglig oppdatert. Deltakelse er obligatorisk for å bli resertifisert som spesialist hvert femte år.

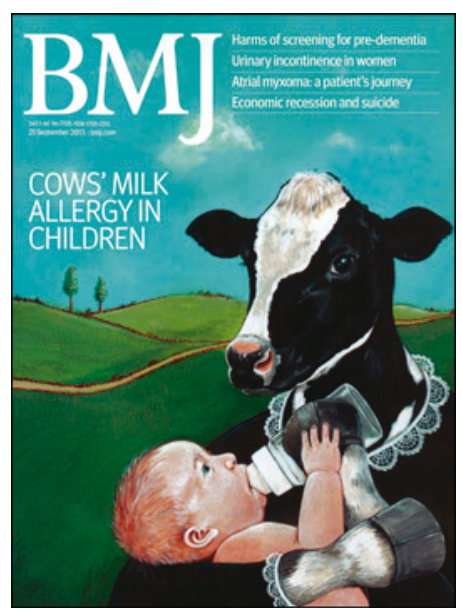

Artikkelen ble e-publisert 26.7. 2013 i $B M J$, som er et av verdens mest anerkjente medisinske tidsskrifter 